IJ§ER

ISSN: 2149-5939
International Journal of Social Sciences and Education Research

Online, https://dergipark.org.tr/tr/pub/ijsser

Volume: 6(3), 2020

\title{
Sustainability of adult education: Andragogues as change agents ${ }^{1}$
}

\author{
Siniša Kušić ${ }^{2}$, Sofija Vrcelj ${ }^{3}$ and Anita Zovko ${ }^{4}$ \\ Received date: 16 / 05 / 2020 \\ Accepted date: 20 / 09/2020
}

\begin{abstract}
The paper analyses andragogues as change agents in education. Starting from critical theory, andragogues have the potential to work within the curriculum redefinition framework by enabling participants in educational process to identify areas of knowledge deficits and build on prior knowledge. In addition to this change, they can carry out transformative learning in which the central category is critical reflection, i.e. the most important characteristic of adult learning. The aim of this paper is to point out the importance of the identity of andragogues and to point out that their role in changing education, especially when in the knowledge society in which lifelong learning is the key to change the individual and society.
\end{abstract}

Keywords: Andragogues, change agents, transformative learning, critical theory, emancipation

\section{Introduction}

Since the time of Kurt Lewin, a theorist who first studied the theory of change and practiced it in the 1940s (Burnes, 2004; Kritsonis, 2004-2005), the concept of change agent has recently become more and more used as a specific social category which designates persons or groups that play a significant role in initiating, managing, or implementing change (Caldwell, 2003; 2005). However, the concept change agent is neither unique nor uniquely defined but is used in different contexts to denote different changes. The change agent can refer to individual actors of a group or a team, or to professionals who have specific competencies in change management. It can also refer to people with visionary abilities, to people outside of a particular system or organization as well as people who are invited to make certain changes in the organization (Lunenburg, 2010). Miller and Lawton (2002) define change agents as invisible hands that turn vision into action, i.e. they are focused on developing, applying, and advocating good and successful practices. For change, growth and successful practices, agents can provide specific solutions in advance. The second type of agent is oriented towards mutual understanding and mutual decision making with the participants (Ackoff, 1981).

The vagueness of the concept is enhanced by a different understanding of change that can signify both radical change but also minor innovations and interventions at the macro or micro level (Caldwell, 2005). When it comes to change, it can be said that there are almost as many concepts of the change process as there are authors who analyse this phenomenon. Change

\footnotetext{
${ }^{1}$ This paper is the result of research projects (Critical Discourse of Didactic Models and CompetencesTeachers in Adult Education (Anita Zovko) and Andragogy workers and education for sustainable development (Siniša Kušić).

${ }^{2} \mathrm{PhD}$. Assistant professor, University of Rijeka, Faculty of Humanities and Social Sciences, Department of Education, Croatia, skusic@,ffri.uniri.hr

${ }^{3} \mathrm{PhD}$. Full professor, University of Rijeka, Faculty of Humanities and Social Sciences, Department of Education, Croatia, svrcelj@ffri.uniri.hr

${ }^{4} \mathrm{PhD}$. Full professor, University of Rijeka, Faculty of Humanities and Social Sciences, Department of Education, Croatia, anita.zovko@ffri.uniri.hr
} 
Kušić, S., Vrcelj, S., Zovko, A. (2020) Sustainability of adult education: Andragogues as change agents. International Journal of Social Sciences and Education Research, 6(3), 443-449.

includes change of the organization of environmental structures, technologies or people. Change sometimes involves innovation, and the ultimate goal is to improve outcomes through change in practice (Shen, 2008; Kritsonis, 2004-2005). Change can be said to be a process of learning and implementing new ideas to improve practical experience. Furthermore, in terms of scope and participants, changes can be implemented on the state, community, institution, group or individual level. It is also possible to talk about social, political, climate, educational, technological, communication, family and other changes.

Although there is no agreement on the precise determination the change agent, there is an agreement on their importance as they are a success factor for facilitating the work of an organization and / or group (Van Poeck, Læsšre and Block. 2017).

Considering that almost all segments of human life are changeable, this paper is dominantly orientated towards changes in adult education, respectively to andragogues who are determined to be the change agents. By andragogues we mean qualified people whose scope of work is not only adult education, but they are professionals working in manufacture, business world, military, mass media, various educational institutions and other fields. Namely, the need to redefine andragogues arises from educational practices that sometimes impose the necessity of clearly delineated target groups. For andragogues, the criterion of creating a professional identity is the age of the students they work with, and the upper and lower age limits depend on narratives formulated by educational policy makers themselves (Ranzijn, 2010), which can contribute to the redefinition of andragogues. In Europe, adults are often defined as people over 30, making it difficult to conceptualize education and employment. Given the considerable economic disparities within the European area, biological age is a problematic criterion since, for example, material independence and personal autonomy are more important criteria separating young people from adults (Shanahan, 2000). Regardless their identity is not being clearly defined because there is an understanding that anyone who works with adults is an andragogue, we can say that andragogues - no matter where they work, are specialists in change (Reischmann, 2017; 2017 a). We can analyse these changes at the level of what individuals can do to develop their effectiveness as drivers of change, despite the system being slow. Andragogues cannot depend on the system and wait for the system to change if they want sustainable emancipatory education.

\section{Andragogues as change agents - critical emancipatory discourse}

In education reforms in many countries around the world, there is a tendency for teachers to be explicitly determined as change agents. This shift is significant considering the dominant policy was aimed at deprofessionalization because teachers were perceived as executors of certain curricula in order to achieve a repressive testing regime and to meet the criteria of external evaluation (Priestley, Biesta \& Robinson, 2012; Guilherme, 2008; Freire 2002). Defining a teacher as a change agent primarily includes action and critical thinking within a particular context, which is the reason why andragogues are viewed as change agents from the discourse of critical emancipatory pedagogy (Freire, 2002). Their power of change is reflected in the aspect of emancipation, liberation, and the development of critical awareness of oppression, and in the critical reflection on educational policy and official curricula. Emancipatory learning questions the power of language and the nature of experiences, and the activity of the andragogue (the teacher) is aimed at helping adult learners imagine the radical possibilities of educated minds and educated

Copyright (C) by International Journal of Social Sciences and Education Research ISSN: 2149-5939 
Kušić, S., Vrcelj, S., Zovko, A. (2020) Sustainability of adult education: Andragogues as change agents. International Journal of Social Sciences and Education Research, 6(3), 443-449.

citizenship, using analytical tools that allow for questioning and resistance to accepted models of thinking.

From the perspective of constructivist theory, andragogues can redesign the curriculum in such a way that it allows participants in different segments to identify areas of knowledge deficits and to build on prior knowledge.

Traditional pedagogy is based on the power relations of those who have the power of knowledge versus those who do not have that power, and is oriented towards the creation of "products" tailored to the country or tailored curricula and knowledge created by the commanding ones. Antionio Gramsci (1891-1937) believed that "hegemony is a political practice and a continuous process performed by the ruling class with one purpose - to preserve both power as well as intellectual and moral leadership" (Sućeska, 2013:40). He is the one to indicate that the ruling class presents itself as an organism capable of absorbing the whole society, bringing it to its own cultural and economic level, i.e. by the means of hegemony the state becomes an educator (Sućeska, 2013). Hegemony was organized by intellectuals and their task is to shape moral and intellectual life. The intellectual function within a given society is always educational and political and intellectuals are not determined by the type of work they do, but by the function of political and technical leadership.

Education is an area where theory and practice, culture and politics, research and achievement inevitably merge in combination with social and political activities (Ferreira and Bittar, 2008). Accumulated knowledge is selectively and ideologically coloured through various institutions in society. Universities, for example, deal with knowledge in two ways (Hayes, 2006). They, on the one hand, reproduce new generations through education (and knowledge) and, on the other, they create an explicit epistemological logic for such knowledge, creating a standardization of theoretical methods for obtaining new knowledge (Ferreira and Bittar, 2008). Theory thus becomes an ideology that is not an instrument for understanding reality, but a set of moral principles for directing actions and human behaviour. Education is oriented towards a technicity approach, so students and teachers are shaped not to promote freedom, democracy or criticism.

Education provides mispresented images of the world and promotes values and worldviews that marginalize individuals according to the criteria of class, sexuality, gender, and other characteristics (Hayes et al. 2011). Some contents are either inadvertently overlooked in the curriculum, such as the contribution of women or other groups to a community or society in general. Critical theorists, however, believe that the official curriculum is tailored to the needs of the dominant groups, because the curriculum defines entitlement to powerful knowledge. (Young, 2014). Unlike traditional pedagogy, critical pedagogy is oriented toward education and knowledge as a set of autopoietic practices characterized by autonomous personality formation, freedom of individual thought, decision-making and action. Critical pedagogy places hope in education that should be encouraged in gaining different experiences as well as in giving freedom to determine one's authentic identities (Vrcelj, 2018). The emotional and intellectual autobiography of the student /the subject of education is the direction of andragogue's work that needs to be embraced and incorporated into the work plan and used in the selection of models and methods of adult education.

Authentic identities and autobiographies open the space for andragogues to be change agents considering that traditional pedagogy did not adequately take them into account. Their power of 
Kušić, S., Vrcelj, S., Zovko, A. (2020) Sustainability of adult education: Andragogues as change agents. International Journal of Social Sciences and Education Research, 6(3), 443-449.

change is thus reflected in the aspect of emancipation, liberation, and the development of critical awareness of oppression, and in the critical reflection of educational policy and official curricula.

Official curricula are often tailored to work with children and young people without adequate teaching content that is appropriate for adult learners. In redesigning the curriculum, it is necessary to consider the full range of learning experiences and numerous contexts provided by the educational institution, which can be implemented in adult education. From the perspective of constructivist theory, andragogues can redesign the curriculum in such a way that it allows participants in different segments to identify areas of knowledge deficits and to build on prior knowledge. Teachers should have enough space to contribute to the community, to create national and world values that treat those that are different fairly and with a high level of tolerance. Change-oriented curricula will not leave andragogues powerless in achieving the individual's real growth and emancipation (Watkins, 2010). Accordingly, in the implementation of the curriculum, andragogues should include in the evaluation their beliefs about what the community should be in order to ensure that investment in education produces long-term good results for all, not just those belonging to or aspiring to educational hegemony (Siegel, 2006; White, 2014).

As Dewey (1966) points out, education should contribute to social integration, the overall improvement of society and be an incentive for individuals to develop their full potential. In the emancipatory discourse of education, andragogues have a wide range of ways and modalities for introducing and developing social competencies in the preparation and continuous improvement of the education curriculum. In addition, in critical thinking, they also emerge as individuals who change social competences that are important for collective learning and for social life. Significant space for andragogues is thought to be created in the change process of learning associated with transformative learning, founded by Freire. His concept conscientização was embraced by Jack Mezirow (1991), who researched the return of women to post-secondary education or to the workplace. He wanted to identify factors that are affirmative or limiting in the women's adjustment upon their return to previously abandoned activities. Transformative learning is the process of causing change in the frame of reference - i.e. adults have acquired a coherent experience (associations, concepts, values, feelings) that define their world.

Reference frames are structural assumptions through which we understand our experiences. Our experiences shape and delimit expectations, perceptions, insights, and represent our course of action (Mezirow, 1991). For transformative learning theory, the central category is the critical reflection (Imel, 2000; Mezirow, 1991) that the authors take as the most important characteristic of adult learning. Critical reflection allows us to recognize how much our own biography has limited us. A person develops this ability to evaluate no sooner than in adulthood. To be a victim of a limiting autobiography means to look at your past as a determining factor for your present and your future (Mezirow, 1991). Mezirow points out that J. Habermas introduced the concept of instrumental, communicative, and emancipatory or reflective learning. Each type of learning has a different purpose. Instrumental learning is orientated and happens through problem-solving and by discovering cause and effect relationships. Instrumental learning gives us knowledge about how to control and manipulate the environment or other people through problem solving with the aim of improving performance. Communicative learning, which refers to learning that is related to understanding the perspectives and meanings of others when communicating with us and most commonly related to communication regarding feelings, values, ideals, moral decisions, freedom (Jovanovic, 2014; Mezirow, 1991).

Copyright (C) by International Journal of Social Sciences and Education Research ISSN: 2149-5939 
Kušić, S., Vrcelj, S., Zovko, A. (2020) Sustainability of adult education: Andragogues as change agents. International Journal of Social Sciences and Education Research, 6(3), 443-449.

Habermas's third type of learning - emancipatory, is transformed by Mezirov (1991) into a transformative process. Transformative learning has several phases - 1) Disorientation doubt any external factor that changes the status quo and these factors are some traumatic events such as death of a relative, divorce, separation or unemployment even though these may be accompanied by other factors (discussion or book). 2) Self-examination involving feelings of fear, guilt or shame. 3) Critical evaluation of the assumptions made regarding the role and experience of alienation in relation to traditional social expectations. 4) A person links his / her own dissatisfaction with the similar experiences of others, thus recognizing that our problem is common. 5) Explore opportunities for new roles, relationships and actions. 6) Planning the action. 7) Acquiring competencies for planned action(s) 8) Temporarily experimenting with new roles and evaluating feedback. 9) Building competence and confidence in playing new roles and 10) reintegration into society dictated by a new perspective.

Although this theory has been criticized for starting from the assumption that development comes when we change something that is wrong. This suggests that the person is tasked with transforming, forgetting the circumstances and the world we live in (Maksimovic, 2012). It is thought that andragogues can help marginalized groups because democratic discourse is central to transformative learning (Mezirow, 1991). In the vocabulary of neoliberal politics, the outcome of transformative learning is change. O'Sullivan, Morrel, and O'Connor (2002, according to Gregorcic, 2019) define them in five basic categories, ranging from changes in basic settings and thinking to changes in feelings, actions, and awareness, to a broader, cosmopolitan perception of the world.

Andragogues in the context of transformative learning have to know the needs and goals of their (adult) students and help them act accordingly. In this way, adult learners are afforded the space of critical reflection of what they will do, as well as the autonomy that is important for autopoietic practices that are characterized by autonomous personality formation, freedom of individual thought, decision-making and action.

There are different limitations in the change process since education does not exist in a theoretical and practical vacuum. It should however be emphasized that achievement-oriented education as measured by standard tests and market requirements respects the previous experience of adults and creates such relationships in the educational process that do have an emancipatory dimension.

\section{Conclusion}

The modern school system and educational institutions, as an integral part of it, are large and complex bureaucratic systems that, regardless of their management mode, are regulated at the state and school levels by various laws and regulations. Determining the goals of education, especially in neoliberal conditions, is characterized by political, economic, ideological, cultural and other factors rather than didactic, andragogical and pedagogical ones. The goals of education, and then the goals of reforms as a way out of the education crisis, are an expression of political rivalry and power play between individual interests, dominant groups' value systems, and the needs of social groups that feel marginalized. Education is deeply ingrained into society and it can prevent and repel change, however the status of an andragogue as a change agent is fundamentally changing. The barriers to adult education that andragogues try if not to eliminate than to adapt are becoming clearer. Emotional and intellectual autobiographies of adults are the guidelines for 
Kušić, S., Vrcelj, S., Zovko, A. (2020) Sustainability of adult education: Andragogues as change agents. International Journal of Social Sciences and Education Research, 6(3), 443-449.

andragogues' work and these need to be embraced and incorporated into their work plan. In such way andragogues become change agents.

Although the social context is not always conducive to the work of andragogues, it should be noted that andragogues can and often do encourage critical thinking and develop socio-cultural education related to (adult) life practices. By working in this way, realistic assumptions of democratization are realized, as well as balancing the internal, external and personal perspective of change, not only in special institutions for adult education, but also beyond.

Andragogy activities are much broader than working in traditional educational institutions. Their role is most important in changes towards a knowledge society in which lifelong learning is the key to changing the individual and society as a whole.

\section{References}

Ackoff, R. (1981). The Art and Science of Mess Management. Interfaces, 11(1), 20-26. Retrieved from http://www.jstor.org/stable/25060027.

Badley, G. (1986). The Teacher as Change Agent. Journal of In-Service Education, 12:3, 151-158, DOI: $10.1080 / 0305763860120305$

Bourn, D. (2015). Teachers as agents of social change. International Journal of Development Education and Global Learning, 7 (3).

Burnes, B. (2004). Kurt Lewin and the planned approach to change: A re-appraisal. Journal of Management Studies, 41 (6), pp. 977-1002. https://doi.org/10.1111/j.1467-6486.2004.00463.x.

Caldwell, R. (2003). The changing roles of personnel managers: old ambiguities, new uncertainties. Journal of Management. Studies ,40 (4), pp. 983-1004.

Caldwell, R. (2005). Things fall apart? Discourses on agency and change in organizations Human Relations. Volume 58(1): 83-114. DOI: 10.1177/0018726705050937

Ferreira, A. i Bittar, M. (2008). Education from the marxist perspective: an approach based on Marx and Gramsci. Interface, v. 12, n. 26, p. 635-646, Jul./Set. 2008.

Fullan, M.G. (1993). Why Teachers Must Become Change Agents. Educational Leadership, Vol.50, Number 6 March.

Freire, P. (2002). Pedagogija obespravljenih. Zagreb: Odraz - Održivi razvoj zajednice.

Gregorčič, M. 2019, Pedagoške smjernice za emancipacijsko učenje. PYLE: Post-YU for Learning Emancipation - Supporting learners on the way to self-realisation. http://www.vci.hr/site_media/media/cms_page_media/52/IO1-\%20HRV\%20prijevod_VCI_final_3.pdf

Giljerme, M. (2008). Uloga kritičke pedagogije u kulturnim studijama - intervju sa Anri. A. Žiruom. Pedagogija, 63(1), 5-16.

Hayes, K., Steinberg, S. R. i Tobin, K. (eds.) (2011). Key Works in Critical Pedagogy: Joe L. Kincheloe. Rotterdam/Boston/Taipei: Sense Publishers.

Hayes, W. (2006). Progressive Education Movement: Is it Still a Factor in Today's Schools? Rowman \& Little_eld Education.

Jovanović, A. (2014) .Transformativno učenje u romanu Hermana Hesea Sidarta. Andragoške studije, broj 1 , jul 2014, str. 137-170.

Killeen, Martin P. (2009). The acquisition of information and learning technology skills by FE teachers. EdD thesis, University of Nottingham.

Kritsonis, A. (2004-2005). Comparison of Change Theories . International Journal of Scholarly Academic Intellectual Diversity. Volume 8 Number 1 2004-2005

Copyright (C) by International Journal of Social Sciences and Education Research ISSN: 2149-5939 
Kušić, S., Vrcelj, S., Zovko, A. (2020) Sustainability of adult education: Andragogues as change agents. International Journal of Social Sciences and Education Research, 6(3), 443-449.

Lunenburg, F.C. (2010). Managing Change: The Role of the Change Agent. International Journal of Management, Business, And Administration, Volume 13, Number 1.

Maksimović, M. (2012). Teorije učenja i odnosi moći u obrazovanju odraslih. Andragoške studije, broj 1, jul 2012, str. $37-62$ I

Merriam, Sharon B.(2002) Andragogy and Self-Directed Learning: Pillars of Adult Learning Theory. New directions for Adult \&Continuing Education, Vol. 2001, Issue, 89.

Mezirow, J. (1991). Transformative Dimensions of Adult Learning. San Francisco: Jossey-Bass.

Miller, K., \& Lawton, R.L. (2002). The Change Agent's Guide to Radical Improvement https://www.amazon.com/Change-Agents-Guide-Radical-Improvement/dp/0873895347\#reader_0873895347.

Priestley, M., Biesta, G, Robinson, S. (2012). Teachers as agents of change: An exploration of the concept of teacher agency. Working paper no. 1, Teacher Agency and Curriculum Change (ResearchGate).

Reischmann, J. (2017). What are Andragogues good for? Workplaces, Competencies, Study Contents, Identity. Andragoške studije, br.1. str.9-24.

Reischmann, J. (2017a), Lifewide learning - Challenges for Andragogy. Journal of Adult Learning, Knowledge and Innovation, 1(1), pp. 43-50 (2017) DOI: 10.1556/2059.01.2017.2

Shen, Y. (2008). The Effect of Changes and Innovation on Educational Improvement. International Education Studies. Vol.1. N.3.

Sućeska, A. (2013). Koga obrazuje obrazovanje? Gramsci i hegemonijska funkcija obrazovanja. U: Perica, I. (ur.), POLITICKO_PEDAGOŠKO. Janusova lica pedagogije. Zagreb: Udruga Blaberon.

Tikly, L., Barrett, A.M, (2011). Social justice, capabilities and the quality of education in low income countries. International Journal of Educational Development, 31 (2011) 3-14.

Vrcelj, S. (2018). Što školu čini školom-teorijski pristupi, koncepti i trendovi. Rijeka, Filozofski fakultet.

Young, M. (2014). Curriculum theory: what it is and why it is important. Cadernos de Pesquisa.. [online].vol.44, n.151, pp.190-202. 